\title{
Álruhában a semmi közepén \\ Megközelítési szempontok Bret Easton Ellis regényeihez
}

\author{
Molnár Bálint
}

\author{
Disguised in the Middle of Nowhere \\ Aspects of Approach to the Novels of Bret Easton Ellis
}

\begin{abstract}
This paper attempts to interpret the early novels of Bret Easton Ellis titled Less Than Zero and American Psycho. It consists of two main parts: the two novels themselves and the attempts at interpreting the questions raised by them. The first section unfolds Ellis' first novel's reception, then it tries to explore its reference system: social problems, intermediate and materialist elements, motifs of the aforementioned generation. The second section of the paper concentrates on the worthily famous third piece of the Ellis life work titled American Psycho and the emerging problems and phenomena connected to it. Based on the creation and reception of the novel, it tries to line up those moments which could serve as the base of the critical voices as well as it tries to explain them. At the end the research focuses on the motif of the serial killer and on the question of the fictive narrator's world.
\end{abstract}

Keywords: minimalism; postmodern; mediality; MTV-generation

Kulcsszavak: minimalizmus; posztmodern; medialitás; MTV-generáció

Subject-Affiliation in New CEEOL: Language and Literature - Studies of Literature

- Other Language Literature

DOI: 10.36007/eruedu.2021.1.056-071

\section{Elöszó}

Bret Easton Ellis regényeiröl egyre több kiváló szakirodalom és tanulmány születik, nem véletlenül. Írásművészetében összetett utalásrendszerekkel találkozik irodalomtörténész, kritikus, a tágabb értelemben vett olvasó egyaránt. Jelen dolgozat a szerző két korai müvét vizsgálja: a Nullánál is kevesebbet és az Amerikai Psychót. A tanulmány célja az általam kiemelt értelmezések összegzése, továbbá egy áttekinthető kép kialakítása arról, hogyan és miként, mely vonalak mentén lehet megkísérelni Ellis életművének esetleges további elemzéseit. 
Bár Ellis regényei kapcsolatban állnak egymással és folyamatosan utalnak egymásra, mégsem tekinthető az életmü poétikai szempontból egységesnek. A szerző első két regényénél (Nullánál is kevesebb; A vonzás szabályai) felfedezhető minimalista eszközkészletétöl már jelentékenyen eltér harmadik könyvében, az Amerikai Psychóban. Az intermediális elemek megidézésével, a valós és az imaginárius, valamint a parodisztikus megoldások révén sokkal inkább a posztmodern mozzanatokat juttatja eszünkbe. S bár sokan a szerzőt épp az e regénye körül kialakult botránya miatt ismerték meg, mára teljes bizonyossággal kijelenthető, hogy jelentősége írói világában rejlik, melyben mesterien tárgyalja többek között a társas kapcsolatokat, a fogyasztói társadalmat és a materializmust, mindezt különféle médiumok (szöveg, magazin, kép, mozgókép, zene) közbejátszásával.

Az Ellis-próza egy olyan dilemmát tár elénk, mely a médiakultúra általi közvetítettségben és az irodalom szerteágazóbb lehetőségeiben rejlik. Ez a kérdés nyilván többféle olvasatot indukál, nem mellesleg a társadalmi szatíra, valamint a mediális szempontú kultúra- és irodalomértelmezés számára is perspektívát kínál. Ellis különösen az Amerikai Psychóban - egy olyan világot mutat be kiválóan, amelyet egyre inkább a mainstream médiakultúra képei és szimbólumai alkotnak, ugyanakkor a szexualitás és az erőszak megjelenítési módjai is szorosan összefüggnek a fogyasztói társadalommal és a tömegmédia dominanciájával. Nem szabad elfelejteni azonban, hogy a szimulákrum fogalmával írható le ez a jelenség, hiszen a szerző szövegeiben megjelenített problémáknak épp abban rejlik az egyedisége, hogy az önmaguk és a médiák által létrehozott szimulációiban létezik csupán. De ne szaladjunk ennyire elöre!

A történet és a morál iránti közömbösség mellé a részletek iránti elkötelezettség párosul Ellis regényeiben, melyek minden felháborodásával és ellentmondásos fogadtatásával együtt is hatalmas sikereket eredményeztek. S ha valaki mélyebben szeretné tanulmányozni a szerző munkásságát, fel szeretné tárni a szöveg mögötti tartományokat és összefüggéseket, valamint szövegszervezési eljárásait, annak feltétlenül érdemes fellapoznia Fodor Péter és L. Varga Péter kiváló monográfiáját, melynek címe: Az eltünés könyvei: Bret Easton Ellis, s melyre dolgozatunk is támaszként tekint.

\section{A semminél jóval több, azaz: Nullánál is kevesebb}

Az 1985-ben megjelent Nullánál is kevesebb egy csapásra kimozdította a 20 éves Bret Easton Ellist a hagyományos egyetemista évek monoton hétköznapjaiból. A szerző ugyanis részt vett egy „kreatív írás” nevü kurzuson, melyet egy akkori bestseller-író, Joe McGinnis vezetett. Tulajdonképpen az ő nevéhez köthető a regény kiadatása, aki felfedezte tanitványában a tehetséget, bátoritása és közremüködése által közösen dolgozták át, majd adták ki a regényt 1985-ben (Schumacher 1988, 124). A regény a piacra kerülése után szinte azonnal sikereket könyvelt el, majd két évvel később, 1987-ben megfilmesitették és az amerikai mozik müsorára is felkerült. 
Az amerikai minimalista irodalom klasszikus példájának számító regény azonban korántsem ok nélkül jelent meg (és jelenik meg a mai napig) jelentős tanulmányok és elemzések fókuszában. A szerző ugyanis már az első regényében kiválóan hozza játékba pl. azokat az eljárásmódokat, melyek a minimalizmus és a posztmodern kivételes viszonyát tárják elénk. Gondoljunk csak a felszínes karakterábrázolásra, a hétköznapi ember premier plánba hozatalára, a mindennapi valóság tárgyainak és aktivitásainak megidézésére, valamint az egész helyett a részletek hangsúlyozására. A regény fiktív világa idegennek, erőszakosnak, kíméletlennek tűnik, a morált érintő kérdésfelvetések esetében pedig felmerül a probléma, hogy vajon az olvasásra vonatkozó tudásunk lesz-e konzervatív, vagy ezt a szemléletváltást csupán a minimalizmus és a posztmodern különös párbeszéde produkálja (Fodor - L. Varga 2012, 14).

Ahogy már a bevezetöben is említettem, a szerző müvei kapcsolatban állnak egymással, mégpedig nem akárhogy: azon kívül, hogy folyamatosan utalnak egymásra, több párhuzam is felfedezhetö bennük (egyébként az MTV-generációs szerzők müvei között is átfedéseket vélhetünk felfedezni, de erről bővebben majd egy következő alkalommal szólunk). A főszereplők például a korábbi regényekből a későbbi történetekben mellékszereplőként jelennek meg újra. Így fordulhat elő az, hogy Clay, a Nullánál is kevesebb főszereplője a Vonzás szabályai című regényben egy mellékszereplő, és az olvasó megtudja, hogy mi lett belőle - pontosabban azt tudja meg, hogy semmit sem változott. De említhetnénk Patrick Batemant és Victor Wardot is, akik a Vonzás szabályaiban még szintén csak mellékszerepeket játszanak, később Ellis azonban „nekik szenteli” az Amerikai Psychót és a Glamorámát is. Párhuzamként emlithetjük továbbá a szubjektum kilétének az elbizonytalanítását, az erőszak iránti fogékonyságot, a visszatérő és állandóan ismétlődő motívumokat, valamint a sokszor értelmetlennek tünő párbeszédeket és gondolatfoszlányokat. Ahogyan Deisler Szilvia (Deisler 2009, 114) vagy Stemler Miklós (Stemler 2001, 1-2) is megemlítik tanulmányaikban, a regényt mindenképp érdemes elözményként kezelni, hiszen elörevetít olyan szerepeket és történéseket, melyek az Amerikai Psycho és a Glamoráma kulcskérdései lesznek. Felvezeti továbbá az erőszakot is, mely teljes egészében csak a későbbi regényekben bontakozik ki. Ha már szóba kerültek a párhuzamok, érdemes rávilágítani az ellentétekre is, azok közül is a leglátványosabbra: Ellis korai regényeinek (Nullánál is kevesebb; A vonzás szabályai) minimalista eszközkészletétöl az Amerikai Psycho és a Glamoráma is jelentősen eltér, mégpedig a „,szerteágazó intertextuális és intermediális utalásrendszer, a metafiktiv és parodisztikus megoldások, valamint a valós, a fiktív és az imaginárius mozzanatok kontaminácója" révén (Fodor - L. Varga 2012, 10).

A Nullánál is kevesebb cselekményét nem szükséges részletesen elemezni. Leginkább talán azért, mert egyszerüen nem lehet nem egyetérteni a szerző szavaival, melyek szerint ebben a regényben „,nincs helye a cselekménynek”. Ellis konkrétan így nyilatkozott egy méltán híressé vált interjúban: „meghatározó a céltalanság, az értelmetlen téblábolás, és egyszerüen nincs helye a történetnek. Az általam legkevésbé kedvelt szakasz a Less Than Zeróban az az utolsó negyed, ahol mintha kezdene megjelenni valami elörehaladó cselekményszerüség" (Schumacher 
2003, 92-93). Érdemes azonban megemlíteni, hogy ez az interjú a nyolcvanas évek végén készült Ellisszel. A későbbi regényeiben, különösen a Glamoráma és a Holdpark esetében már egyre inkább úgy tünhet az olvasónak, hogy Ellis megbarátkozott a cselekmény lehetőségével. Habár az egyes fejezetek nem igazán kapcsolhatók össze, mégis fellelhető két cselekményszál, mely többször visszatér, illetve végigkíséri a regényt. Az egyik ilyen Clay és Blair fokozatosan kibontakozó viszonya, a másik pedig Julian leépülése, züllése a kemény drogok és a prostitúció által. Peter Freese megállapítja, hogy a két szereplő, Blair és Julian a látszólag cselekménytelen regényben egyfajta keretet képeznek, mind a ketten feltünnek a mü elején és a végén is (Freese 1990, 72-73).

\section{Recepciótörténet}

A regény fogadtatása kifejezetten szélsőséges és megosztott volt. A probléma hátterében maga a mü olvasata és annak nehézségei álltak. A negatív reakciókat általában a könyv felszínes, felületes és egyszerünek ható stílusa, nyelvezete váltotta ki (Gray 1985, 80). Ez az olvasat viszont önmagában véve is ironikus: azon kritikusok, akik a regényt felszínesnek és felületesnek ítélték, tulajdonképpen a saját olvasatukról tettek tanúbizonyságot, melyre sokkal inkább igazak lehetnek a fentebb emlitett jelzők. Freese és Steur annak idején válaszokat kerestek arra, hogy miért is itélte el több kritikus a müvet. A probléma eredetét abban vélték felfedezni, hogy a Nullánál is kevesebb egy olyan generáció szimbólumait és kódrendszereit tartalmazza, melyeket csak a „,beavatottak”, azaz pontosan csak az adott generációba és időbe tartozók érthetnek meg (Steur 1995, 16; Freese 1990, 69). Olyan materiális, technikai és mediális utalásrendszerekröl van itt szó, amelyek az érintett kritikusok számára egyszerüen nem elérhetők. Erre a jelenségre nézzük meg példaként a regény címét. A Nullánál is kevesebb egy idézet, mely az énekes Elvis Costellótól származik. Less Than Zero volt Costello első lemezének a címe, mely 1977-ben jelent meg Nagy-Britanniában. Az akkori fiatalabb generáció számára ez az utalás sokkal egyértelmübb volt, mint pl. egy átlagos kritikus számára. Voltak azonban recenzensek, akik felismerték ugyan a könyv címének eredetét, de értelmezési hibák egész sorát követték el. A legismertebb példa erre az, amikor Peter Freese a dal metaforikus jelentését emelte ki és nemes egyszerüséggel összekeverte a dalban szereplö Oswaldokat (Freese 1990, 83). Úgy értelmezte, hogy Costello a dalában Lee Harvey Oswaldra utal, holott ez nem így volt. Sir Oswald Mosley volt a dal hőse, aki a British Union of Fascists-ot alapitotta. Costello ezzel a hetvenes években Nagy-Britanniában újra teret nyerő fasiszta és nacionalisa mozgalmak ellen próbált meg állást foglalni (Steur 1995, 150-153). Láthatjuk tehát, hogy bár sokan felismerték, hogy Costello egy dalszövegének idézetéröl van szó, a regény címét még így is többször félreértelmezték.

A dalszövegeknél maradva érdemes megemlíteni azt a jelenetet, amikor Julian Tom Petty Straight into Darkness című dalának egy sorát dúdolja: „we went straight into darkness, out over that line, yeah straight into darkness, straight into night" (Ellis 1985, 40). Ha az elemzö kiragadja ezt a sort és kontextusba helyez- 
vén értelmezni próbálja a jelentése alapján, akkor több mint valószínü, hogy Julian érzéseivel fogja azonositani: ez a részlet a reménytelenségre, az elveszettségre, a közeledő végre utal. Érdemes lehet viszont figyelembe venni a szám teljes szövegét (ami a müben nem jelenik meg), és láthatjuk, hogy az utolsó strófában már felbukkan az optimizmus és az újrakezdés reménye. Steur például ezek alapján Juliant olyan karakternek tekinti, aki egy önámítás áldozata, és a dal végén vizionált jobb élet reményébe kapaszkodik (Steur 1995, 181-183).

A recepciótörténet feltérképezésénél érdekes állomás lehet még Nicki Sahlin esszéje is, melynek címe: But This Road Doesn't Go Anywhere: The Existential Dilemma in Less Than Zero. A szerző a tanulmányában a regény egzisztencialista elemeit vizsgálja és megállapítja, hogy ezek leginkább Camus és Sartre elegyeként értelmezhetők (Sahlin 1991, 25). Clay elidegenedve érzi magát a társadalomtól, mert Hollywood anyagias értékrendszere végül önromboláshoz vezethet. Ez az elidegenedés üzi őt az egzisztencialista önkeresés felé. Abádi Nagy Zoltán szerint azonban a minimalista ember nem tud, vagy nem is akar menekülni, csupán elvágyódik. Clay és a többiek soha nem néznek egymásra, amikor egymással beszélnek. Ezzel egyrészt a kommunikációba is hiba csúszik, másrészt pedig a nagyon mélyen eltemetett jobbik én jelzi benne ösztönösen az oda nem tartozást. Clay viszont nem fogja fel, hogy elvágyódik, egyszerüen megmarad a kifelé nézés szűnni nem akaró állapotában (Abádi 1994, 242-243). „Sokkal érdekesebb dolgok történnek egy könyvben annál, hogy szereted-e a karaktereket vagy sem - a szöveggel kapcsolatos technikai dolgok, vagy a narratív kifejtés illetve ki nem fejtés módjai" (Schumacher 2003, 89). Ezt maga Ellis nyilatkozta a már említett interjú alkalmával, amikor arról volt szó, hogy sokan nem úgy dolgozták fel és fogadták be a regényt, ahogy azt maga a szerző elvárta volna. Sőt, gyakran azonosították annak szereplőit Ellisszel, ami igencsak problematikus hozzáállás. Itt azért megjegyezhetö, hogy több gyanús önéletrajzi elem is bekerült a regénybe, ami csapdába csalta az efféle nézeteket vallókat: a szerző életkora, Los Angeles-i jómódú családi háttere, nagyapjának a kaszinója, két húga stb. Sokkal fontosabb azonban a szöveg irodalmi megalkotottsága, a rövid és gyors tempójú egységek, a felszín alatti szövegelemek, a szövegen belüli utalásrendszerek megfejtése, valamint a regény más szövegekkel való párhuzamba állítása. A tradicionális, lineáris cselekményvezetés helyett Ellis körbejárja az eseményeket, pillanatfelvételeket mutat be, melyek öszszegződéséből felépül(het) egy történet. Ellis szerint a filmszerü megjelenítésmód is teljes mértékben szándékos volt: „Nagyon fontos volt, hogy a regény filmszerü legyen, hogy az írás integrálja a film nyelvét. Emlékszem, milyen nagy hatással voltak rám a Robert Altman-filmek - különösen a Nashville, és annak csodálatos és lenyügöző technikai megoldásai" (Schumacher 2003, 91).

\section{Társadalmi dilemmák}

„Az emberek félnek belekeveredni...” A regény kezdőmondata, mely többször is megjelenik egyfajta vezérmotívumként, nemcsak az idegentől való félelemre, az egymással szembeni közönyösségre utal, hanem sokkal inkább arra a kapcsolat- 
rendszerre, mely eredetileg a biztonságot és bizalmat, szeretetet és megértést feltételezi, más szóval a családra, amit Ellis regényében pont ezen jegyek ellentéte ábrázol, tehát a bizalmatlanság, a kapcsolathiány, a családtól való félelem. Ez a jelenség már a regény kezdetén kibontakozik, és végig szemtanúi lehetünk. Clay és anyja, illetve a két húga közti viszony egyértelműen azt mutatja, hogy a társas kapcsolatoknál szinte minden fontosabb. A regény hősei számára ugyanis a legnagyobb, s talán az egyetlen érték a fogyasztás, az anyagi szükségletek folytonos kielégítése, a materializmus minden lehetséges formája: a korlátlan és céltalan vásárlások, a reklámok tömkelege, sztárok és márkák, plázák és szupermarketek. Sőt, a történet még ennél is továbbmegy: a szereplök saját maguk válnak árucikké. „Bárcsak ő lenne eladó!” (Ellis 2010, 27) - ez a tipográfiailag is megkülönböztetett mondat a regényben előfeltételezi a későbbi eseményeket, méghozzá azt, ahogy Julian prostituálttá válik. Még a családtagok is kellemetlenül érzik magukat a másik jelenlétében, arról már nem is beszélve, hogy értelmes társalgást egyáltalán nem folytatnak. A gyermek-szülö viszonyra több példa is felhozható lenne, de az alábbi kifejezetten jól szemlélteti az adott problémát:

- Hol vannak a szüleid? - kérdezem.

- A szüleim?

- Aha.

- Asszem, Japánban.

- Mit csinálnak ott?

- Vásárolnak.

- Bólintok.

- De az is lehet, hogy Aspenben vannak - mondja. - Nem tök mindegy? (Ellis 2010, 57)

L. Varga Péter és Fodor Péter az ilyen és ehhez hasonló párbeszédeket vizsgálva az alábbi megállapításra jut: „Amennyiben ezeket a dialógusokat nem pusztán a bennük termelődő kommunikációs deficit társadalomkritikai példaértéke szempontjából vesszük szemügyre, akkor a megszólalások s az őket kísérő szereplöleírások látványosan klisékből építkező jellege tűnhet föl számunkra" (Fodor - L. Varga 2012, 26). A szülők és gyermekeik viszonyával kapcsolatban idézik továbbá Medgyes Tamás értekezését, mely szerint a „Less Than Zero a meg nem értés dokumentuma is, és kifejezetten a kommunikáció lehetőségei és technikái szempontjából reflektál a problémára, némi öniróniával" (Medgyes 2003, 19). A parodisztikus elemek, az irónia és a groteszk szintén meghatározó eszközökké válnak Ellis regényében. Fontos szerepet töltenek be a különféle bulvárlapok és azok ábrázolásmódjai, ráadásul maguk a szereplök a szüleik tartózkodási helyéröl is ezekből az újságokból szereznek tudomást. Ellis gyakran - szintén ironikus módon - felborítja az olvasó elvárásait. Remek példa erre Claynek és a pszichiáterének az esete, amikor a segítségre szoruló, már-már zokogó Clay egyáltalán semmiféle segítségre nem számíthat orvosától, sőt a történetből kiderül, hogy tulajdonképpen a pszichiátere szorul kezelésre, ő az, aki egyfolytában beszél, s a betege a hallgatósága (Ellis 2010, 125-126). Nem ez az egyedüli példa arra, hogy a regényben 
valamilyen módon a szerepcsere elve érvényesül. A szövegben fellelhető ironikus hang segítségével próbál a főszereplő egyfajta távolságot tartani mindentől, amivel esetleg nem tud azonosulni. Az már más kérdés, hogy ez mennyire sikerül neki. Az elbeszélő pusztán közvetíti azt, amit lát, a leírások mentesek mindenféle kommentártól - Fodor Péterék szerint ez lehet az irónia forrása a müben (Fodor - L. Varga 2012, 46). Ide tartoznak még az állandóan ismétlödő mondat- és gondolatfoszlányok, visszatérő motívumok, mint pl. „Itt eltünhetsz”; „Az emberek félnek belekeveredni”; „Bárcsak ő lenne eladó”, vagy a különböző jelzők: pénzes, szőke, barna, napszemüveges stb. A repetíció effajta funkciója szintén az irónia jelenlétére enged következtetni, valamint a kiüresedett, körben forgó lét hangsúlyozására. Itt jöhet képbe az identitás és individualitás kérdésének problematikája is, mely a Nullánál is kevesebb esetében kiemelkedő jelentőséggel bír. A materializmus mint az egyedüli értékrend a regényben olyan erős, hogy az embereket nemcsak hogy irányítja, hanem egyenesen elnyeli és árucikké, valamint teljesen egyenlővé teszi. A szöke hajú, lebarnult, napszemüveget viselö karakterek tökéletesen egyformák és felcserélhetök.

Ellis hősei állandóan úton vannak, a történet fö szervező struktúrája a folyamatos helyszínváltás és az utazások, ezért nem meglepő, hogy Stemler Miklós szerint a mü akár „roadregényként” is olvasható. Ugyanakkor ezek az utazások valójában céltalanok és csak a körkörös ismétlödésen van a hangsúly, melyet a narráció szintjén a camera-eye technika teremt meg. Ez abban nyilvánul meg, hogy az elbeszélő érzékelö automata módjára rögzíti a történéseket, és csak nagyon kevés teret hagy a reflexióknak, valamint az ok-okozati viszonyok összekapcsolása sem müködik (Stemler 2001, 1-2). Ez jól megfigyelhető például akkor, amikor Clay barátnője segítségért „,kiált”, de ő csak az esemény mechanikus rögzitésére képes, arra azonban már nem, hogy esetleg a kérés gyakorlati voltát felfogja, megértse, hogy ténylegesen „,segítsen rajta”: „...valaki piros filctollal, gyerekes macskakaparással telefirkálta az asztalt azzal, hogy "Segíts rajtam«" (Ellis 2010, 123). Ez az ironikus olvasat még tovább erősödik a fentebb említett pszichiáter karaktere révén, aki groteszk módon szintén nem veszi figyelembe betege segélykiáltását. Erre a passziv recepcióra szintén jó példa lehet az is, amikor Clay elkíséri elzüllött és prostituálttá vált barátját, Juliant, hogy egy sokkal idősebb férfivel folytatott nemi együttlétét nézze meg. A szintén sokat idézett mondat ekkor hangzik el: „És hogy csak az számít, hogy látni akarom a legrosszabbat" (Ellis 2010, 176). Stemler Miklós véleménye szerint Clay az így szerzett tapasztalatait nem tudja értelmezni, ezt a passziv recepciót pedig a tévénézés folyamatához hasonlítja, mely a regény egészén végigvonul.

Nem mellesleg a szöveg erénye, hogy a témakörön kívül maga az elbeszélés is képes „lemodellezni” ezt a fajta életszemléletet (Stemler 2001, 1-2). A tévénézés egyébként a zenével összhangban jelenik meg, hiszen csakis kizárólag az MTV-t, azaz a zenecsatorna müsorait nézik. A televízió mint a passzivitás vitathatatlan eszköze, az MTV a Nullánál is kevesebbhez tartozó tanulmányokban, értelmezésekben mindig visszatérő témaként jelenik meg, sőt a müvet a megjelenése után MTV-regénynek is nevezték. Ahogy korábban említettem, a filmszerü megjelenítésmód Ellis részéröl teljes mértékben szándékos volt. Ezt támasztják alá többek között a regény mediális elemei is: a zenei utalások, a televízió, az MTV állandó 
jelenléte, a magazinok és bulvárlapok, a videoklipek és a videóklipként müködő pergő párbeszédek és fejezetek. A különböző médiumok állandó jelenlétéhez hozzátartozhat az is, hogy a szereplök nagy zenerajongók (egyébként Ellis maga is az, sőt zenekara is volt), erröl árulkodnak a poszterek és plakátok, kazetták és videók. A már említett regénycímen kívül is számos Elvis Costello-utalás jelenik meg a müben. Ezenkívül zenei utalásként működnek a dalszövegek és dalcímek, melyek nagyon érdekes funkcióval bírnak: elörevetítik a későbbi eseményeket. A szövegben elöforduló intermediális utalásrendszereket rendkívül pontosan elemző Fodor Péter és L. Varga Péter megállapítja, hogy Ellis már ebben a könyvében különleges érzékenységet mutat regényszöveg és technikai médiumok összetársitása terén: „a tér és időmegjelöléssel kezdődő rövid jelenetek, melyek olykor maguk is egymáshoz lazán kapcsolódó képekböl állnak, a gyakori és hirtelen vágások az 1981ben induló, tehát a regény születésekor nagyon friss zenecsatorna által sugárzott, kevert médiumú és műfajú videoklip müködésével állíthatók párhuzamba" (Fodor - L. Varga 2012, 53).

Természetesen az itt felsorakoztatott médiumközi utalásokon kívül még számos ilyen található a regényben és azok folytatásaiban egyaránt. Az viszont, hogy ez miIyen olvasási stratégia bevonásával válik érthetővé, hogyan válik rendeltetésszerü eszközévé a regénynek, függ attól, hogyan épül be a szövegbe, illetve, hogy mely jelentésrétegeik válnak erőteljesebbé a rekontextualizáció által.

\section{Ahonnan nincs kijárat: Amerikai Psycho}

Az Ellis-életmű harmadik darabja, a hírhedtté vált Amerikai Psycho a szerző legnagyobb port kavaró regénye lett, melyröl a mai napig jelennek meg újabbnál újabb tanulmányok és értekezések. Az alábbiakban nézzünk meg olyan jelenségeket és párhuzamokat, melyek fontosak lehetnek az elemzések szempontjából.

Ahogy az előző fejezetben már emlitésre került, a Nullánál is kevesebb címü regénnyel ellentétben, melyet joggal tartunk minimalista alkotásnak, ebben az esetben sokkal inkább a posztmodern sajátos jegyeit vélhetjük felfedezni. Gondoljunk csak az irónia, reflexivitás, elidegenítés, intertextualitás adta lehetőségek kiváló alkalmazására. Bán Zsófia szerint azonban nem a minimalizmus kontra posztmodern paradigmaváltásáról van itt szó; a regény „,sokkal inkább a modernizmus zárt/nyitott műveinek rendszeréből a posztmodernizmus »nyitott szerialitásába« való átmenetet képezi” (Bán 2004, 5). Egy olyan összetett elbeszélői szerkezettel találja magát szembe az olvasó, mely az elbeszélés médiumának fontosságát helyezi előtérbe, ezzel is eltávolítva Ellist a minimalizmustól. Ebben a regényben az irónia még nagyobb szerepet tölt be, általa mutatja be a szereplőit és azok konzumvilágát, melyek tulajdonképpen a tömegkultúra termékeiként és ezzel egyidejüleg a paródiájaként müködnek.

Az Amerikai Psycho ugyanúgy nem szolgál az olvasó számára összefüggő cselekménnyel, mint az elődje, a Nullánál is kevesebb. Az a cselekményszál, mely ott nehezen ugyan, de identifikálható a Clay és Blair általi kapcsolat fokozatos tönkremenéseként, itt már a hősök önmaguk összetörésével válik egyenértékűvé. Míg a 
regény első harmadában Bateman (a főszereplö) felszínessége, az ő ismeretségi köre és az egész yuppie-társadalom bemutatása jelenik meg, addig a második harmadban a karakterek azonossága és egymással való felcserélhetősége rajzolódik ki, mely Paul Owen meggyilkolásának jelenéténél fejeződik ki leginkább. Az emberek egyenértéküsége és egyfajta felcserélhetősége lehet az egyik fő oka Bateman belső szenvedésének, mely a későbbi történésekben előtérbe helyeződik, és ez lehet az oka annak, hogy a regény utolsó harmadának elejétől kezdődően megsokszorozódnak az erőszakos cselekedetek. Bateman brutalitásának csúcspontját egy vad ámokfutásban, a Hajsza, Manhattan címü fejezetben éri el. Ez után a tetőpont után a regény ismét lassabb ütemüvé válik, és többek között az is világos lesz az olvasó számára, hogy Bateman sosem fog leállni, hogy továbbra is gyilkolni fog, mert abból a „pokolból”, amelyben ő él, és amit ő képvisel, nincs kijárat. Így nyerhet végül megerősitést a regény kezdőmondata és Dante művének jól ismert intertextusa, a KI ITT BELÉPSZ, HAGYJ FEL MINDEN REMÉNNYEL a mű végén, a zárómondat által: NEM KIJÁRAT.

\section{A fogadtatás és az azt befolyásoló zavaró jelenségek}

Az Amerikai Psycho az a könyv, amely már a megjelenése elött is óriási vitákat generált, és irodalomtörténeti szempontból is jelentős a recepciótörténete. Ennek oka rendkívül összetett és szerteágazó, az alábbiakban megpróbálom összegezni, hogy miért.

L. Varga Péterék felhívják a figyelmet arra, hogy ez a regény egy speciális eset, mégpedig abban a megközelítésben, hogy azzal szembesíti kutatóját, hogy az irodalmi nyilvánosság már nem korlátozódik a szerzők, könyvek, szövegek, kritikusok, irodalomtudósok körére. Az irodalom mint üzem müködésénél - ezáltal a regényt körülvevő vitánál is - már olyan mellékszereplők is a diskurzus résztvevőivé váltak, mint például a szerkesztőségi munkatársak, kiadóvezetők, könyvtárosok, könyvkereskedők, társadalmilag elkötelezett „olvasók”. Az is sokatmondó, hogy mennyire új keletü dolog volt az, hogy ilyen rétegek is az irodalmi nyilvánosság részesei lettek. Ellis a kialakult botrány után azt mondta, hogy a regényírás során legfeljebb arra számított, hogy a sorozatgyilkosok fognak tiltakozni ellene (vö. Fodor - L. Varga 2012, 85). Megemlíthető még maga a médiaesemény is, mely hatalmas méreteket öltött és rengetegen tettek szert hírnévre épp a regény kritizálása által.

A regény kiadása elött a Time és a Spy magazinokban megjelent két rövid, ám korántsem erőszakmentes részlet a regényböl, mely nagyban hozzájárult a könyv megjelenését ellenző kampány kialakulásához. Az eredeti kiadó, a Simon \& Schuster - mely 300000 dollárral megelőlegezte a készülö müvet - egyszerủen viszszalépett és nem adta ki a könyvet, melyet azzal indokolt, hogy a jó ízlés és társadalmi felelősség mindennemü haszonszerzésnél fontosabb számukra. Ez abban az 1990. december 16-án megjelent New York Times-cikkben olvasható, mely az imént említett két magazinközlésre reflektált és a teljesség igénye nélkül az alábbi elmarasztaló jelzőket használta: szadista, undorító, gyűlöletes, utálatos, értelmetlen, egészségtelen, értéktelen, ócska, hulladék (Rosenblatt 1990). Ahogy monda- 
ni szokás, a negatív reklám is reklám, sőt a regény kézirata negyvennyolc órán belül elkelt. A Knopf, a Random House leányvállalata vette meg a jogokat, majd 1991 márciusában megjelent az Amerikai Psycho. A kiadás után egyre több feminista véleményformáló lépett színre, akik általában a nők ellen elkövetett erőszakokat nehezményezték a könyvben. Ezen kívül a regényt erőszakosan elítélö és elutasító kritikai reakciók egész sora látott napvilágot, melyet már számos tanulmány és szakirodalom részletesebben elemez, így én nem tartom lényegesnek azok újbóli summázását (bővebben pl. Fodor - L. Varga 2012, 83-93; Sári 2010; M. Nagy 1999). Mindannyiunkban felmerül azonban a kérdés: mégis mi lehetett az oka annak, hogy ez a regény - az Egyesült Államok történetében egyedülálló módon ennyire „kiverte a biztositékot”? Tegyünk egy próbát a kérdés megválaszolására!

Ellis első regénye ugyanúgy hemzseg az erőszakos cselekedetektöl. Ennek ellenére, ha párhuzamot vonunk a Nullánál is kevesebb és az Amerikai Psycho agresszív jelenetei között, akkor megállapíthatjuk, hogy az elbeszélői alapelv újrafogalmazásával van dolgunk, hiszen a korábbi mü történetmondója, Clay megfogalmaz egy nagyon minimális és bizonytalan indoklást arra, hogy miért sétáljon ki abból a szobából, ahol a tizenkét éves kislányt megerőszakolják: „...nem hiszem, hogy ez helyes" (Ellis 2010, 194). Az 1991-ben megjelent regény azonban nem szolgál semmiféle morális fogódzóval - és pontosan ebben rejlik az, ami a szöveg hatását alapvetően meghatározza. Az elmarasztaló kritikák nagy része továbbá azt is felrótta, hogy nem derül fény a főszereplő tetteinek belső motivációjára. Az ok-okozatiság hiánya, a föhős motiváltsága, illetve a gonosz méltó büntetése és a világ rendje iránt érzett olvasói igény ilyen formában tehát kielégítetlen marad.

Az olvasás során a befogadó általában megpróbál azonosulni az elbeszélővel, esetleg valamely szereplővel. Itt jelentkezik a következő probléma, mely az olvasó számára szokatlan, furcsa, esetleg zavaró hatást kelthet: egyszerüen képtelen azonosulni az elbeszélövel. A korabeli kritikák például azt is nehezményezték, hogy Ellis ,agyatlan fogyasztóként” ábrázolja a manhattani yuppie-kat. Sári B. László nagyon helyesen világít rá arra, hogy Patrick Bateman a kulturális fogyasztás „értő kritikusaként” és nem hétköznapi fogyasztóként jelenik meg a regényben. Az Amerikai Psycho azt a kényes társadalmi jelenséget is ábrázolja, hogy az, ami az elbeszélőnek anyagi jólétéből adódóan bőségesen megadatott, arra az alsó középosztály csupán csak vágyakozhat. Ezért értelmezhető a kritikusok körében az „agyatlan fogyasztó” az utálat jeleként (Sári 2010).

Feltűnő jelenség, ami már a Nullánál is kevesebbnél is megfigyelhető, de itt már halmozottan igaz, hogy az elbeszélő nem rendelkezik identitással. Mindenfajta önazonosságát vagy a televízióból származtatja, vagy azokkal a termékekkel azonositja magát, amelyeket épp vásárolt. Bán Zsófia kijelentésével értünk egyet, melyet már a regényhez írt utószóban kiválóan megfogalmaz: „A regényben a személytelenség, arctalanság pornográfiája tombol, partikularitása, identitása, bizonyossága itt csak a tárgyaknak van, csak a különböző márkanevek ismerhetők fel biztosan, a személyek nem." (Bán 1999, 576) Ez a hatás csak még erőteljesebb lesz, amikor kiderül, hogy Bateman nem az egyedüli, ugyanis senki más nem hiszi, hogy rendelkezne identitással, valamennyien összekeverik egymást. Néha fogalma sincs az elbeszélőnek arról, hogy épp kivel beszél. Ez is kiváló példa az ábrázolt 
társadalomban meglévő szérialét jelenségére: mindenki csinos, jól öltözött és gazdag, így senki sem emlékszik pontosan a másik nevére, söt a meggyilkolt emberek többségét nem is keresik - fel sem merül az egyének hiánya (Kékesi 1996, 71).

Az elbeszélő alapvető állapotában semmit sem csinál, csak vásárol, majd elmeséli, hogy mit vásárolt, hogy milyen zenét hallgatott. Tévét néz, kokaint vág az American Express hitelkártyájával és rendületlenül kozmetikázza magát, majd oldalakat olvashatunk arról, hogy milyen arckrémet használ. A zavaró jelenségek sora egyre nő, amikor kiderül, hogy ezeken kívül azért mással is foglalkozik: nőket ver ruhafogassal, hajléktalanokat kínoz és öl meg, kollégákat gyilkol, nőket és férfiakat csonkit és föz meg, több nőt meg is erőszakol, majd fúrógéppel feldarabol stb. Ellis egy új és különleges eljárást alkalmaz: nem tesz különbséget az elbeszélöi nyelvben. A gyilkosságokat is ugyanazon a szenvtelen hangon közli, mint a korábbi eseményeket, például a vacsoráját.

Félmeztelen vagyok, úgy tanulmányozom magam az X-kluziv kondicionálószalon öltözőjében a mosdókagylók fölötti tükörben. A karizmom duzzad, a gyomorfalam feszesebb nem is lehetne, a mellem akár az acél, a hasfalam kőkemény, a szemem fehérje, mint a jég. Az öltözőszekrényemben három vagina hever, melyeket nemrégiben metszettem ki mindenféle nök testéböl, akiket a múlt héten öltem meg. Kettő már meg is van mosva, a harmadik még nincs. Az egyikre hajcsattal kedves kis svájcisapkát tüztem, a kedvencemre pedig kék szalagot (Hermés) kötöttem (Ellis 2016, 526).

Az elbeszélő számára tehát nincs semmiféle különbség a vásárlás és a mészárlás között. És, hogy a felsoroltakon kívül mit csinál még az elbeszélő akkor, amikor épp nem gyilkol? Például a végtelenségig sorolja a márkaneveket, különös tekintettel az ásványvizek típusaira, vagy szinte már szaklapokba illö leírásokat ad kedvenc együtteseiröl, énekeseiről. Fodor Péter és L. Varga Péter felveti annak a gondolatmenetnek a lehetőségét, mely szerint: „az azonos szintaktikai funkcióval bíró elemek halmozása, a személynevek és árucikkek leltárszerü felsorolása, a személyiség ismételhetőségének és kicserélhetőségének tapasztalata Andy Warhol sorozatképeit is fölidézheti" (Fodor - L. Varga 2012, 122).

Az itt felsorolt zavaró jelenségek összessége kellett ahhoz, hogy ennek a regénynek a befogadása, a körülötte kialakult viták irodalomtörténeti szempontból is emlékezetesek maradjanak. Hiszen jól látható, hogy a fentebb említett (és a nem említett) kritikák többségében megfogalmazódott egy fontos alaptétel: nincs morális ítélethozatal, nincs sikeres nyomozás, nincs lelkiismeret-furdalás és nincs vége a gyilkolásnak sem. Az erőszak megtestesülését pedig nem egy külső - mint ahogy azt a Nullánál is kevesebb elbeszélője, Clay teszi -, adott esetben például egy nyomozó szemszögéböl, hanem a gyilkoséból, belső nézőpontból mérjük fel. Ez a gyilkos azonban a befogadó számára szokatlan: nincs explicit módon kifejezett indítéka a gyilkosságokra. Az indíték mondhatni maga a gyilkolás. Továbbá, hogy a hatás még erősebb legyen, a laikus olvasó még ígéretet sem kap, de még csak nem is reménykedhet abban, hogy Pat Bateman befejezi a vérengzést. 


\section{„Én egy közveszélyes pszichopata vagyok.” Vagy mégsem?}

A regény olvasójának egy idő után bizonyára feltünik, hogy Bateman fokozottan érdeklődik a sorozatgyilkosok iránt. Ez az első olyan tulajdonsága, mellyel kitünik a társai közül. Erre kiváló példa, amikor egy párbeszéd során a barátainak felemlíti Ed Geint és az ő álláspontját a nőkröl, aki először elgondolta, milyen lehet rendesen megismerkedni egy nővel és beszélgetni vele, végül, hogy miként mutatna a feje egy pózna végén. A társai ezzel a közbeszólással nem tudtak mit kezdeni, zavarukban felnevettek (Ellis 2016, 134). Világosan kiderül a szöveg egészéből, hogy egyes bünözők tevékenységével teljesen tisztában volt, többször hivatkozott rájuk, gyakran már példaképnek is tekintette öket. Így talán nem elhamarkodott az a kijelentés sem, hogy cselekedeteiben szerepe lehetett sorozatgyilkos és ámokfutó „elödjeinek”, melyek valós történelmi személyiségek, brutális gyilkosságaikat valóban elkövették. Ed Gein és Jeffrey Dahmer például szexuális és kannibalisztikus vágyait élte ki áldozatain, Gein ráadásul azok húsát és bőrét felhasználva különféle tárgyakat is készitett. Patrick foglalkozott más sorozatgyilkosokkal is. Meghatározó volt számára például Ted Bundy, akinek a nevéhez harminc gyilkosság füződik, aki ugyanúgy külsőre a megnyerő, intelligens oldalát mutatta, de áldozatai között szintén megtalálhatók nők és fiatal lányok, sőt még egy tizenkét éves is. Bundyt végül 1989-ben kivégezték, épp abban az évben, amikor Ellis megkezdte a regény írását. Nagy érdeklődéssel figyelte továbbá Charles Manson és David Berkowitz „pályafutását” is. A regény főszereplője egyszerre szolgál kriminológiai és filmtörténeti mintázatként, ugyanis a hasonlóság tagadhatatlan Bateman karaktere és a klasszikus slasher horrorok szadista elkövetöi között (Fodor - L. Varga 2012, 109). A filmes médiumok tekintetében érdekes kérdés lehet, hogy $A$ texasi láncfürészes mészárlás, vagy épp Freddy Krueger karaktere miért volt befogadhatóbb a közönség, a nagyérdemű számára. Ezek a filmek a müfaj abszolút klasszikusainak számítanak, ugyanúgy telítve vérengzéssel és erőszakkal. A válasz erre valószínűleg abban rejlik, hogy ezek az alkotások mind szolgálnak egyfajta indoklással, lélektani magyarázatokkal.

Ed Gein történelmi jelentőségü brutalitása azért sem elhanyagolható, mert az Amerikai Psychón túl más jelentős művek inspirációjaként is szolgált. Ő adta az ihletet például Buffalo Bill karakterének megformálásához is, $A$ bárányok hallgatnak címü regény és annak filmadaptációjához egyaránt. A Thomas Harris által írt regény 1988-ban jelent meg és nagysikerü klasszikussá vált, dijazott darab lett. A siker tovább halmozódott, amikor 1991-ben elkészült a filmes adaptációja is Jonathan Demme rendezésében: öt Oscar-dij, Golden Globe- és BAFTA-dijak, számos egyéb elismerés és jelölés. Ugyanebben az évben jelent meg az Amerikai Psycho is, amely - egy kis túlzással - szinte teljesen ellentétes fogadtatásban részesült. Ennek oka rendkivül egyszerü. A bárányok hallgatnak címü könyv, illetve a film is esztétikai kategóriákban gondolja el és interpretálja a gyilkosságokat, a morális borzalmat. Azt a látszatot próbálja kelteni, mintha az áldozatok nem valódi emberek, hanem csak müalkotások lennének, amit az FBl-ügynöknek kell megfejteni. Az áldozatok tulajdonképpen térképként müködnek a gyilkos megtalálásának folyamatában. Nagyon fontos, hogy bár a gyilkosságok legalább annyira kegyetlenek, mint 
Ellis regényében, itt mindig a nyomozó szemszögéböl látjuk az eseményeket, és mindig annak reményében, hogy a végén az elkövető elnyeri méltó büntetését. Ezzel szemben az Amerikai Psycho esetében az elbeszélés kizárólag a gyilkos szemszögéből zajlik, aki ugyanúgy kezeli az embereket, mint a fogyasztási cikkeket. Az Ellis által ábrázolt világ teljesen áttekinthetetlen mind számunkra, mind a gyilkos számára a regényben. A bünre következő bünhődés narratívája nem valósul meg. Nincs lehetőség a megváltásra és nincs lehetőség a bünhődésre és a büntetésre sem ebben a világban - a per technikai okok miatt elmarad, ugyanis nincs, aki ítélkezzen felette, sem ő maga, sem senki más (Bán 1999, 575). A regényben nem alakul ki az a külső perspektíva, mely a bünügyi történetekben (pl. A bárányok hallgatnakban) a nyomozó munkája által jön létre, s amely nem pusztán a mi történt, de a miért történt kérdésre is válasszal tudna szolgálni (vö. Fodor - L. Varga 2012, 109). A regény olvasása alatt, illetve után okkal merül fel a kérdés: a főszereplö, Bateman ténylegesen elköveti-e agressziv cselekedeteit, vagy ez pusztán a képzeletének a szüleménye? Bán Zsófia szerint amennyiben az utóbbi lépne érvénybe, akkor az effajta értelmezés azonnal ártalmatlanná tenné a könyvet - tehát idealizálná azt. Felveti továbbá azt a tényt is, mely szerint a mü egyfajta szimulákrumként is müködik, hiszen az a valóságnak egyenrangú része, megismétlése, ugyanis a könyv megírása önmagában is a könyvben leírt szörnyüségek sorozatába illik (Bán 2004, 8).

Julian Murphet teljes meggyőződéssel állítja, hogy Bateman tettei csupán a képzeletének a szüleményei (Murphet 2002, 48). Owen eltünése szerinte nem lehet bizonyíték a gyilkosságra, hiszen több karakter is indokolatlanul köddé válik a regényben, gondoljunk csak Tim Price-ra. Nagy valószínűséggel egy megbízhatatlan elbeszélővel van dolgunk, hiszen csak töle értesülünk arról, hogy lemészárolta Paul Owent, majd szintén töle tudjuk meg, hogy találkozik vele az utcán. És arról sem feledkezhetünk meg, hogy Bateman vallomását egy olyasvalaki próbálja meg cáfolni, aki egyáltalán nem nevezhető megbízható külső távlatnak, hiszen hogyan lehetne Harold Carnes állításának hinni, ha ő maga Davis Donaldsonnak véli Batemant? A regény befogadásánál tehát még annak a kérdésnek a megválaszolása is problémás, hogy vajon mi tekinthető a fiktív világban reálisan megtörténő eseménynek (Fodor - L. Varga 2012, 113). Az immanens világ egycsapásra megkérdőjelezödik, amikor a korábban meggyilkoltról kiderül, hogy életben van. H. Nagy Péter rávilágít arra, hogy a regény narratív szerkezetét nem pusztán „egy történet elbeszéléseként” kell értelmeznünk, és az alábbi megállapításra jut: „Paul Owen története felszámolódik, elbeszéléseiben létezik pusztán, melyek (jelen esetben) az eldöntetlenség alakzata mentén »rendeződnek “. Fontosabb lehet természetesen, hogy eme kontingenciát csakis az olvasó trópusa írhatja bele a regény szövetébe, hiszen az elbeszélésben nem reflektálódik e viszony" (H. Nagy 1999, 117). A valós és az imaginárius közti viszony egyre feszesebbé válik azáltal, hogy a fikcióképző aktus folyamatosan emeli át a márkák, szereplők, szórakozóhelyek és cégek neveit a külső kontextusból, azaz a tömegkultúrából. A főszereplő, Bateman által nézett filmek és a különböző müsorok pedig a szó szerinti átvételekről tanúskodnak. Ezzel együtt meg kell azonban jegyezni, hogy nem húzható éles határ a valós és a fiktív között a regényben, ugyanis a Hajsza, Manhattan címü fejezet kivételével én-el- 
beszélés müködik. Sokkal inkább a kettő egymásba játszása történik (vö. Seress 2003, 116).

A kettős én megléte azért is problémás kérdés és azért sem jelenthető ki egyértelmüen, mert Bateman tudatosan próbálja meg felhívni a társai figyelmét arra, hogy valami nincs rendben. Folyamatosan jelzéseket tesz a felszín alatti énjéröl, amit azonban a körülötte lévő világ teljes mértékben figyelmen kívül hagy. A regényben már az első fejezetben bevallja, hogy kicsoda is ő valójában: „Ő egy nagyon helyes kisfiú, igaz-e, cucikám? - Nem éppen - motyogtam magamban - én egy közveszélyes pszichopata vagyok" (Ellis 2016, 34). Itt szintén jól látható az a már-már parodisztikus különbség, ahogyan a külvilág tekint Batemanre és ahogy Bateman tekint saját magára. Másik kiváló példa: amikor társai megkérdezik, hogy mihez van kedve, így válaszol: „Én a legszívesebben... péppé verném egy nő arcát egy téglával" (Ellis 2016, 445). Eszünkbe juthat még az a rész is, amikor tömeggyilkosnak öltözik egy halloween-buliban, de nem ö nyeri dijat, mert nem volt eredeti a jelmeze - holott mint a részböl kiderül, nagyon is az volt (Ellis 2016, 468). Ezek a jelenetek tovább erősítik a regény ironikus olvasatát.

Érdekes és egyáltalán nem elhanyagolható tény, hogy Ellis egy jóval későbbi regényében, a Holdparkban az elbeszélö által hogyan nyilatkozik a vizsgált kérdéskörünkröl és az Amerikai Psychóról. A könyvben egy ál-önéletrajzi narrátorral találkozunk, melyröl részletesebben Fodor Péterék könyvének vonatkozó fejezetében olvashatunk (Fodor - L. Varga 2012, 193-205). Ellis (így hívják ugyanis az elbeszélőt) világos álláspontot fogalmaz meg, mellyel tulajdonképpen igazat ad Murphet korábbi feltételezéseinek és az imént emlitett téziseknek is:

Amellett Patrick Bateman nyilvánvalóan megbízhatatlan elbeszélö, és ha az ember ténylegesen elolvassa a könyvet, alighanem kételkedni fog benne, hogy ezek a büncselekmények egyáltalán megtörténtek-e. Komoly célzások voltak arra, hogy csak Bateman agyában játszódtak le. [...] A társadalomról szólt meg az erkölcsökröl és szokásokról, és nem nök feldarabolásáról. Hogyan olvashatta a könyvet bárki is úgy, hogy ezt nem látta? (Ellis 2008, 210-211)

Összességében viszont hiba lenne csakis kizárólag ezen kijelentésekre támaszkodni és Bateman fantáziavilágával magyarázni mindent, ezzel egyidejüleg pedig figyelmen kívül hagyni az erőszak ábrázolása által kialakult hatást. Ellisnek ugyanis elképesztően kifinomult módon sikerült az olvasót manipulálni az erőszak megjelenítésével. Az olvasónak az a reménye, mely szerint az agressziv cselekedetek, gyilkosságok csupán csak az elbeszélö képzeletében történtek meg, további bizonyiték a regény müködésének hatékonyságára. Nem elhanyagolható az a tény sem, hogy ahogyan Patrick cselekedetei egyre brutálisabbak, mellette ugyanúgy egyre nevetségesebbek is. Innen nézve egyértelmü, hogy a regény megjelenésekor hangoztatott „szépirodalom megalázása” szóba sem jöhet - sokkal inkább a tömegkultúra eszközkészletének paródiájáról van szó (vö. Seress 2003, 118).

Megállapitható az is, hogy Ellis regényeiben a különböző médiumok által formált világ veszi át az emberi kapcsolatok helyét, melyek folyamatosan üresednek ki és szünnek meg, a kommunikációra képtelen szereplők és elbeszélök pedig önkén- 
telenül esnek áldozatául e kegyetlen és könyörtelen univerzumnak. Fontosnak tartom hangsúlyozni azt is, hogy a regények során fennáll az ironikus olvasat lehetösége, mely biztosítani tudja azt, hogy a szöveg távolságot tartson önmagától - ezért tud ennyire kiválóan müködni a fogyasztói társadalom szatirikus kritikusának, Bret Easton Ellisnek a szövegvilága. Arra azonban, hogy ezt mindenki megértse, csak e remekművek elolvasása (és újraolvasása) után adatik lehetőség.

\section{Irodalom}

Abádi Nagy Zoltán (1994): Az amerikai minimalista próza. Budapest: Argumentum.

Bán Zsófia (2004): Túl a minimalizmuson. Paradigmaváltás Bret Easton Ellis Amerikai Psychojában. Prae, 2004/2, 5-11.

Bán Zsófia (1999): Yuppikarusz bukása. In: Bret Easton Ellis: Amerikai Psycho. Budapest: Európa Könyvkiadó.

Berta Ádám (2009): Leértékelt áruk a valóság polcán. Prae, 2009/2, 5-14.

Deisler Szilvia (2009): Párhuzamos viszonyok. Partitúra, 2009/1, 113-140.

Ellis, Bret Easton (2016): Amerikai Psycho. Ford. Bart István. Budapest: Európa Könyvkiadó.

Ellis, Bret Easton (2008): Holdpark. Ford. M. Nagy Miklós. Budapest: Európa Könyvkiadó.

Ellis, Bret Easton (2011): Less Than Zero. London: Picador.

Ellis, Bret Easton (2010): Nullánál is kevesebb. Ford. M. Nagy Miklós. Budapest: Európa Könyvkiadó.

Fodor Péter - L. Varga Péter (2012): Az eltünés könyvei. Bret Easton Ellis. Budapest: Palimpszeszt - Prae.

Freese, Peter (1990): Bret Easton Ellis, Less Than Zero: Entropy in the ,MTV Novel'? In: Reingard M. Nischik - Barbara Korte (szerk.): Modes of Narrative. Würzburg: Königshausen \& Neumann, 72-73. Elérhetö: https://www.enotes.com/topics/bret-easton-ellis/critical-essays

Gray, Paul (1985): Zombies Less Than Zero. Time, 1985. Elérhetö: time.com/time/magazine/article/0,9171,958533,00.html

Harris, Thomas (1991): A bárányok hallgatnak. Ford. Faludi Sándor. Budapest: Magvető.

H. Nagy Péter (1999): Imaginárium I. In: Uő: Kánonok interakciója. Budapest: Fiatal Írók Szövetsége.

Kékesi Kun Árpád: Az értelemhiány keresztútjai. Literatura, 1996/1, 61-73.

Medgyes Tamás (2003): Felszínesség, ismétlés, intertextualitás: A kortárs amerikai próza olvasása, Doktori értekezés. Szeged: Szegedi Tudományegyetem. Elérhetö: http://doktori. bibl.u-szeged.hu/id/eprint/75

M. Nagy Miklós (2001): Mert megöltük az összes polipot. Az üresség perverzitása Bret Easton Ellis müveiben. Elérhetö: https://epa.oszk.hu/00400/00458/00044/polip.htm

Molnár Gábor Tamás (2005): Világirodalom a modernség után. Budapest: Hatágú Síp Alapítvány. 
Murphet, Julian (2002): Bret Easton Ellis's American Psycho: A Reader's Guide. New York: Continuum contemporaries - Bloomsbury Academic.

Rosenblatt, Roger (1990): Snuff This Book! Will Bret Easton Ellis Get Away With Murder? The New York Times Book Review. Elérhetö: http://www.nytimes.com/1990/12/16/ books/snuff-this-book-will-bret-easton-ellis-get-away-with-murder.html?pagewanted=all

Sahlin, Nicki (1991): But This Road Doesn't Go Anywhere. The Existential Dilemma in Less Than Zero. Elérhetö: http://www.tandfonline.com/doi/abs/10.1080/00111619.199 1.9933817

Sári B. László: Az új irodalmi érzékenység: az Amerikai pszichó és a transzgresszív regény kialakulása. Elérhetö: http://www.kalligramoz.eu/Kalligram/Archivum/2010/XIX.evf.-2010.-majus/Az-uj-irodalmi-erzekenyseg-az-Amerikai-pszicho-es-a-transzgressziv-regeny-kialakulasa

Schumacher, Michael (2003): Interjú Bret Easton Ellisszel. Ford. Sághy Miklós. Helikon, 1-2, 88-101.

Seress Ákos (2003): Identitás és brutalitás: a személyiség problémája az Amerikai Psychóban. Iskolakultúra, 2003/4, 115-118.

Stemler Miklós (2001): New York-i éjszakák. Ellis-korpusz szilánkjai. Elérhetö: http://magyar-irodalom.elte.hu/prae/pr/200106/28.html

Steur, Horst (1995): Der Schein und das Nichts: Bret Easton Ellis' Roman Less Than Zero. Essen: Die Blaue Eule. 